\title{
EFEKTIVITAS MEDIA PEMBELAJARAN ULEAD VIDEO STUDIO DALAM MENGIDENTIFIKASI INFORMASI TEKS EKSPLANASI OLEH SISWA KELAS VIII SMP NEGERI 10 PEMATANG SIANTAR
}

\author{
${ }^{1}$ Emi Fitry Yani Sembiring, ${ }^{2}$ Diah Eka Sari \\ Program Studi Pendidikan Bahasa dan Sastra Indonesia,Universitas Negeri Medan \\ E-mail: ${ }^{1}$ emifitryyani@yahoo.com, ${ }^{2}$ ekasarium@yahoo.com
}

\begin{abstract}
Abstrak
Penelitian ini bertujuan untuk mengetahui kefektivan media pembelajaran Ulead Video Studio dalam mengidentifikasi informasti teks eksplanasi oleh siswa kelas VIII SMP Negeri 10 Pematang Siantar.Populasi dalam penelitian ini adalah seluruh siswa kelas VIII yang terdiri dari 8 kelas yang berjumlah 210 siswa.Sampel penelitian ini adalah kelas VIII-7 yang berjumlah 25 siswa dan kelas VIII-4 yang berjumlah 25 siswa.Penelitian ini menggunakan metode penelitian eksperimen.Desain penelitian yang digunakan ialan two group posttest design. Berdasarkan pengolahan data diperoleh hasil posttest kelas kontrol dengan rata-rata $=74,6$ dan standar deviasi $=7,95$. Sedangkan hasil posttest kelas eksperimen dengan rata-rata $=91,2$ dan standar deviasi $=11,7$. Dari uji data posttest kelas kontrol dan posttest kelas eksperimen diketahui bahwa kedua data tersebut berdistribusi normal. Data posttest kelas kontrol diperoleh $L_{\text {hitung }}<$ $L_{\text {tabel }}(0.0043<0.173)$ dan data posttest kelas eksperimen diperoleh $L_{\text {hitung }}<L_{\text {tabel }}$ $(0,1092<0,173)$. Sedangkan dari uji homogenitas diperoleh bahwa sampel penelitian ini berasal dari kelompok homogen yaitu $F_{\text {hitung }}<F_{\text {tabel }} \quad 1,47<1,96$. setelah uji normalitas dan homogenitas dilakukan, diperoleh $t_{o}=6.62$. Selanjutnya $t_{o}$ dikonsultasikan dengan $t$ tabel pada taraf $5 \%$ dengan $d f=24$, maka diperoleh sebesar 2.06. Oleh karena itu $t_{o}$ yang diperoleh lebih besar dari $t_{\text {tabel }}$ yaitu 6.62>2.06, maka $H_{a}$ diterima.Hal ini membuktikan bahwa media pembelajaran Ulead Video Studio efektif digunakan terhadap kemampuan mengidentifikasi informasi teks eksplanasi oleh siswa kelas VIII SMP Negeri 10 Pematang Siantar.
\end{abstract}

Kata Kunci: Media Pembelajaran Ulead Video Studio, Mengidentifikasi Informasi, Teks Eksplanasi.

\section{A. PENDAhuluan}

Siswoyo (2007) Pendidikan merupakan usaha sadar dan terencana untuk mewujudkan suasana dan proses pembelajaran agar siswa secara aktif mengembangakan potensi dirinya untuk memiliki kekuatan spiritual keagamaan, pengendalian diri, kepribadian, kecerdasan, 
akhlak mulia, serta keterampilan yang diperlukan dirinya, masyarakat, bangsa, dan negara.Keberhasilan suatu pendidikan dapat ditentukan oleh beberapa komponen, diantaranya: guru, siswa, kurikulum, materi bahan ajar, media pembelajaran, dan metode pembelajaran (Khasanah: 2017).

Arsyad (2008: 2) mengemukakan bahwa guru sekurang-kurangnya dapat menggunakan alat yang murah dan efisien, meskipun sederhana dan bersahaja tetapi merupakan keharusan dalam upaya mencapai tujuan pengajaran yang diharapkan. Di samping mampu menggunakan alat-alat yang tersedia, guru juga dituntut untuk dapat mengembangkan keterampilan membuat media pembelajaran yang akan digunakannya apabila media tersebut belum tersedia. Dari pernyataan di atas, je las bahwa guru bukanlah satu-satunya sumber belajar, tetapi guru merupakan fasilitator yang seharusnya menyediakan media pembelajaran bagi siswa guna tercapainya tujuan pembelajaran.

Standar kompetensi mata pelajaran bahasa dan sastra Indonesia untuk jenjang SMP/MTs di kelas VIII KD 3.9 kurikulum 2013 revisi, siswa mampu Mengidentifikasi informasi teks eksplanasi berupa paparan kejadian suatu fenomena alam yang diperdengarkan atau dibaca.Berkaitan dengan hal tersebut, keterampilan mengidentifikasi informasi teks eksplanasi pada siswa SMP kelas VIII berdasarkan indikator-indikator yang harus dicapai.

Berdasarkan hasil observasi dan wawancara terhadap beberapa siswa SMP Negeri 10 Pematang Siantar, peneliti mendapatkan keadaan dimana pembelajaran bahasa Indonesia kurang diminati oleh para peserta didik. Kemudian guru masih menggunakan media pembelajaran biasa, seperti media buku dan papan tulis.Mereka merasa jenuh dengan media yang digunakan guru.Sehingga minat mereka terhadap pelajaran Bahasa Indonesia kurang. Kenyataannya keadaan sekolah tersebut kurang memungkinkan untuk menggunakan media pembelajaran berbas is teknologi, karena masih memiliki satu infokus dan stop kontak lis trik yang tidak dimiliki setiap ke las.

Senada dengan hal tersebut, pene litian yang dilakukan oleh Taradip, dkk (2013) yang berjudul "Pengaruh Kombinasi Pembelajaran Terhadap Minat Belajar Mahasiswa Pada Mata Kuliah Teknologi Pembelajaran Akuntansi”, yaitu para pengajar masih menggunakan media seperti buku atau modul, sehingga hal tersebut secara tidak langsung akan memengaruhi minat belajar mahasiswa selama pelaksanan perkuliahan tersebut karena tampilan pembelajaran terlihat kaku dan kurang menarik untuk dipandang, sehingga mahasiswa merasa bosan dan mengalihkan perhatiannya ke luar pembelajaran. 
Banyak perangkat-perangkat lunak yang dapat digunakan untuk membuat suatu media pembelajaran yang menarik dalam komputer, Salah satunya yang dapat digunakan untuk merancang media pe mbelajaran adalah Ulead Video Studio.

Penelitian yang dilakukan Cahyono, dkk (2011) mengungkapkan hasil belajar sebelum dan sesudah menggunakan Ulead Video Studio terdapat perbedaan yang signifikan.Hasil belajar setelah menggunakan media Ulead Video Studio mengalami peningkatan dilihat dari hasil nilai minimum dan maksimumnya mengalami peningkatan dan juga nilai rata-rata mengalami peningkatan yang tadinya dibawah nilai 71,00 sekarang nila inya telah melebihi nilai 71,00 yaitu sebesar 78,23.

Berdasarkan uraian yang telah dijabarkan, maka peneliti dapat mengetahui pengaruh media yang akan timbul dari penggunaan media pembelajaran Ulead Video Studio pada hasil belajar siswa pada kompetensi dasar mengidentifikasi informasi teks eksplanasi berdasarkan hasil post-testkelas kontroldan post-testkelas eksperimen.

Berdasarkan latar belakang di atas, maka penulis merumuskan penelitian ini de ngan judul "Efektivitas Media Pemebelajaran Ulead Video Studio dalam Mengidentifikasi Informasi Teks Eksplanasi Oleh Siswa Kelas VIII SMP Negeri 10 Pematang Siantar”.

\section{B. KAJIAN TEORI}

Ulead didirikan pada tanggal 5 Agustus 1989 oleh Lotus Chan, Lew is Liaw, dan Way-Zen Chen. Mereka mendirikan Ulead dengan dukungan Microtek, setelah meninggalkan Taiwan Institut for Information Industry dalam rangka untuk lebih menge mbangkan dan mengkomersialkan warna pertama mereka.

Ulead Video Studio adalah software yang dapat digunakan dalam pembuatan presentase multimedia, merupakan program aplikasi dalam editing video atau yang berhubungan dengan video dan sekarang banyak dimanfaatkan sebagai program untuk membuat media pembelajaran (Raharjo, 2011).

Aplikasi yang sudah berubah nama menjadi Corel Videos Studio ini adalah paket perangkat lunak editing video untuk Microsoft Windows, didistribusikan oleh Ulead System (sebuah divisi dari Corel). Ulead/ Corel Video Studio ini merupakan salah satu software pengolah video namun sebenarnya juga mempunyai kemampuan yang handal untuk mengolah suara (sound editing), mengolah teks dan juga mengolah image.

Kemendikbud (2014: 1) menyatakan bahwa teks eksplanasi adalah teks yang berisi penjelasan tentang keadaan sesuatu sebagai akibat dari sesuatu yang lain yang telah terjadi 
sebelumnya dan menyebabkan sesuatu yang lain lagi akan terjadi kemudian (Darmawan, 2017). Teks eksplanasi adalah teks yang menjelaskan proses terjadinya atau terbentuknya suatu fenomena alam atau sosial.

Teks eksplanasi yaitu teks yang menjelaskan hubungan peristiwa atau proses terjadinya sesuatu. Selain proses perkembangan suatu tempat, teks eksplanasi dapat ditemukan pada bacaan-bacaan lain yang menjelaskan proses terjadinya fenomena alam, sosial, atau budaya. Setiap teks memiliki genre masing-masing.Teks eksplanasi tergolong ke dalam genre faktual. Oleh karena itu, topik-topik yang dipilih harus lah berupa topik yang dapat memperluas wawasan ataupun pengetahuan pembacanya tentang suatu proses.

Adapun yang dimaksud dengan proses merupakan suatu urutan dari suatu kejadian atau peristiwa (Kosasih, 2014: 191). Teks yang bersifat factual dan informative memiliki ciriciri: (1) penggunaan bahasa yang baku, (2) menggunakan istilah-istilah ilmiah, (3) menerapkan teknik penulisan yang tepat, (4) dilengkapi dengan teori atau definisi.

Jadi dapat dis impulkan bahwa teks eksplanasi adalah suatu teks yang berisi penjelasan tentang fenomena alam atau sosial yang berisi keterangan bagaimana proses terjadinya suatu uraian mengenai sebab akibat terjadinya suatu fenomena alam atau sosial.

\section{METODE PENELITIAN}

Metode yang digunakan dalam penelitian ini adalah metode eksperimen dengan desain Two Group Posttest Design.Metode ini merupakan ekeperimen yang dilaksanakan pada dua kelompok yaitu kelompok kontrol dan kelompok eksperimen. Penelitian dilakukan dengan pemberian perlakuan dan tahap akhir peneliti memberi post test. Dari post test kelas kontrol dan kelas eksperimen dapat dilihat efektivitas media pembelajaran Ulead Video Studio dalam mengidentifikasi informasi teks eksplanasi oleh siswa kelas VIII SMP Negeri 10 Pematang Siantar. 


\section{HASIL DAN PEMBAHASAN}

Perolehan data hasil siswa dalam mengidentifikasi informasi teks eksplanasi menggunakan media papan tulis dapat dideskripsikan sebagai berikut.

Tabel 1

Identifikasi Kecenderungan Hasil Tes Kelas Kontrol

\begin{tabular}{c|c|c|c}
\hline Rentang & F. Absolute & F. Re lative & Kategori \\
\hline $85-100$ & 2 & $8 \%$ & Sangat baik \\
$70-84$ & 16 & $64.00 \%$ & Baik \\
$55-69$ & 6 & $24.00 \%$ & Cukup \\
$40-54$ & 1 & $4.00 \%$ & Kurang baik \\
$0-39$ & 0 & $0 \%$ & Sangat kurang \\
\hline Jumlah & 25 & $100 \%$ & \\
\hline
\end{tabular}

Dari tabel di atas diketahui bahwa hasil tes siswa dalam mengidentitikasi informasi teks eksplanasi menggunakan media papan tulis termasuk kategori sangat baik sebanyak $8 \%$, kategori baik sebanyak 64\%, kategori cukup sebanyak 24\%, kategori kurang baik sebanyak $4 \%$, dan kategori sangat kurang sebanyak $0 \%$.

Perolehan data hasil siswa dalam mengidentifikasi informasi teks eksplanasi menggunakan media Ulead Video Studio dapat dideskripsikan sebagai berikut.

\section{Tabel 2}

Identifikasi Kecenderungan Hasil Kelas Eksperimen

\begin{tabular}{c|c|c|c}
\hline Rentang & F. Absolute & F. Re lative & Kategori \\
\hline $85-100$ & 14 & $56,00 \%$ & Sangat baik \\
$70-84$ & 10 & $40,00 \%$ & Baik \\
$55-69$ & 1 & $4,00 \%$ & Cukup \\
$40-54$ & 0 & $0,00 \%$ & Kurang \\
$0-39$ & 0 & $0 \%$ & Sangat kurang \\
\hline Jumlah & 25 & $100 \%$ & \\
\hline
\end{tabular}


Dari tabel di atas diketahui bahwa hasil tes siswa dalam mengidentifikasi informasi teks eksplanasi setelah menggunakan media pembelajaran Ulead Video Studio termasuk kategori sangat baik sebanyak 56\%, kategori baik sebanyak 40,00\%, kategori cukup baik sebanyak 4,00\%, dan kurang sebanyak 0,00\%, dan kategori sangat kurang baik sebanyak 0\%.

Pembahasan pada penelitian ini adalah meliputi, hasil belajar siswa dalam mengidentifikasi informasi teks eksplanasi menggunakan media pembelajaran papan tulis dan hasil belajar siswa dalam mengidentifikasi informasi teks eksplanasi menggunakan media pembelajaran Ulead Video Studio.

Hasil belajar siswa dalam mengidentifikasi informasi teks eksplanasi tanpa menggunakan media pembelajaran Ulead Video Studio termasuk kategori cukup dengan nilai rata-rata 56.56 dengan nilai tertinggi 79 dan nilai terendah 43. Selanjutnya apabila dilihat dari identifikasi kecenderungan nilai kontrol (Y), kategori baik sebanyak kategori sangat baik sebanyak 3 orang (12,00\%), kategori cukup sebanyak 12 orang (40,00\%), dan kategori kurang baik sebanyak 12 orang $(48.00 \%)$. Aspek penilaian tersebut dapat diuraikan satu persatu sesuai dengan indikator pencapaian kompetensi yang harus dicapai peserta didik pada pembelajaran mengidentifikasi informasi teks eksplanasi berdasarkan tingkat kesulitan memahami informasi teks eksplanasi dan kaidah kebahasaan.

1. Mudah : dengan tingkat kesulitan memahami teks eksplanasi kategori mudah, ratarata 18 siswa menjawab benar.

2. Sedang :dengan tingkat kesulitan me mahami teks eksplanasi kategori sedang, ratarata 18 siswa menjawab benar.

3. Sulit :dengan tingkat kesulitan memahami teks eksplanasi kategori sulit, rata-rata 20 siswa menjawab benar.

4. Sangat sulit :dengan tingkat kesulitan memahami teks eksplanasi kategori sangat sulit, rata-rata 20 siswa menjawab benar.

Hasil belajar siswa dalam mengidentifikasi informasi teks eksplanasi menggunakan media pembelajaran Ulead Video Studio termasuk kategori baik dengan nilai rata-rata $77.48 \%$ dengan nilai tertinggi 91 dan nilai terendah 44. Selanjutnya apabila dilihat dari identifikasi kecenderungan nilai eksperimen (Y), kategori sangat baik sebanyak kategori sangat baik sebanyak 14 orang (56,00\%), kategori baik sebanyak 10 orang (40,00\%), kategori cukup sebanyak 1 orang $(4.00 \%)$, dan kategori kurang sebanyak 0 orang $(0.00 \%)$. Aspek penilaian tersebut dapat diuraikan satu persatu sesuai dengan indikator pencapaian kompetensi yang harus dicapai peserta didik pada pembelajaran mengidentifikasi informasi 
teks eksplanasi di bawah ini berdasarkan tingkat kesulitan memahami informasi teks eksplanasi dan kaidah kebahasaan.

1. Mudah :dengan tingkat kesulitan memahami teks eksplanasi kategori mudah, rata-rata 21 siswa menjawab benar.

2. Sedang :dengan tingkat kesulitan me mahami teks eksplanasi kategori sedang, ratarata 22 siswa berhasil menjawab benar.

3. Sulit :dengan tingkat kesulitan memahami teks eksplanasi kategori sulit, rata-rata 21 siswa berhasil menjawab benar.

4. Sangat sulit :dengan tingkat kesulitan memahami teks eksplanasi kategori sangat sulit, rata-rata 21 siswa berhasil menjawab benar.

Siswa yang menjadi sampel dalam ke las kontrol sebanyak 25 orang siswa dan siswa yang menjadi sampel dalam kelas eksperimen sebanyak 25 orang siswa. Pada kelas eksperimen yang menggunakan media pembelajaran Ulead Video Studio memeroleh skor tertinggi untuk setiap indikatornya sebanyak 14 orang siswa (56\%) dalam kategori sangat baik dan 10 orang siswa (40\%) dalam kategori baik, dan dalam kategori cukup sebanyak 1 orang (4\%).

Berbeda dengan data di atas, pada kelas kontrol yang menggunakan media biasa, yaitu media papan tulis, dengan jumlah siswa yang memeroleh skor tertinggi untuk setiap indikatornya sebanyak 2 orang siswa (8\%) dalam kategori sangat baik, sebanyak 16 siswa (64\%) dalam kategori baik, sebanyak 6 siswa (28\%) dalam kategori cukup, dan 1 orang siswa (4\%) dalam kategori kurang baik.

Dari penilaian di atas, membuktikan bahwa penggunaan media pembelajaran Ulead Video Studio dalam mengidentifikasi informasi teks eksplanasi dapat memengaruhi aktivitas belajar dan hasil belajar siswa SMP Negeri 10 Pematang Siantar.Selain itu, tingkat kesulitan memahami informasi sebuah teks berdasarkan pengalaman individu terhadap alam sekitarnya.Dari hasil penelitian yang sudah dijabarkan, bahwa siswa lebih banyak menjawab benar pada teks eksplanasi berkategori mudah sampai sedang, karena mereka lebih memahami isi informasi teks eksplanasi yang sesuai dengan keadaan alam di sekitar mereka dibandingkan teks eksplanasi berkategori sulit dan sangat sulit. 


\section{E. KESIMPULAN}

Berdasarkan hasil analis is data penelitian dan pengujian hipotes is tentang efektivitas media pembelajaran Ulead Video Studio dalam mengidentifikasi informasi teks eksplanasi oleh siswa kelas VIII SMP Negeri 10 Pematang Siantar, bahwa hasil pembelajaran siswa dinyatakan meningkat.Selain karena media yang digunakan, hal ini dapat dilihat dari setiap hasil siswa berdasarkan setiap kategori tingkat kesulitan dalam memahami informasi teks eksplanasi. Semakin sulit tingkat kesulitan teks tersebut, maka siswa akan semakin sulit menjawab setiap butir soal dari teks eksplanasi, karena tingkat pemahaman siswa berdasarkan tingkat pengetahuan dunia dan penga laman yang te lah dimiliki harus sesuai dengan teks yang dibaca. Semakin mereka tidak memiliki pengalaman atau pengetahuan dunia tentang isi dari teks eksplanasi tersebut, maka semakin sulit mereka memahami isi informasi di dalam teks tersebut dan akan sulit mengidentifikasi informasi dari teks eksplanasi tersebut. Sebaliknya, berdasarkan hasil analis is data penelitian dan pengujian hipotes is tentang mengidentifikasi informasi teks eksplanasi menggunakan media papan tulis, bahwa hasil nilai siswa kelas kontrol lebih rendah dibandingkan hasil nilai siswa kelas eksperimen.

\section{F. SARAN}

Berdasarkan hasil penelitian pada siswa ke las VIII SMP Negeri 10 Pematang Siantar, maka dapat diberikan saran-saran sebagai berikut: (1) Ketika hendak melakukan penelitian menggunakan media yang mengharuskan penggunaan infokus, peneliti sulit mendapatkan alat-alat yang dibutuhkan. Sehingga disarankan agar sekolah memiliki media yang memungkinkan dan cukup untuk melakukan pembelajaran sesuai dengan K13 yang diterapkan sekarang; (2) Se lama kegiatan belajar mengajar, siswa kurang memiliki keinginan untuk menanyakan sesuatu yang berhubungan dengan permasalahan yang di sajikan, Sehingga disarankan untuk lebih melatih siswa dalam mengajukan pertanyaan yang berhubungan dengan fenomena yang didemonstrasikan kepada siswa dengan ilustrasi yang lebih menarik lagi; (3) Selama kegiatan belajar mengajar, peneliti cukup sulit mengatur manajemen waktu untuk keseluruhan kegiatan pembelajaran yang akan dilakukan karena harus mengatur media pembelajaran terlebih dulu. Sehingga disarankan untuk yang ingin meneliti selanjutnya, hendaknya bisa mengatur waktu lebih baik. 


\section{DAFTAR PUSTAKA}

Arsyad, Azhar. 2008. Media Pembelajaran. Jakarta: PT RajaGrafindo Persada.

Cahyono, Dwi Nur. 2011. Peningkatan Kualitas Pembelajaran Ulead Video Studio.Jurnal Pendidikan. Volume (11):1.

Darmawan, Gani. 2017. Pembelajaran Mengidentifikasi Informasi dalam Teks Eksplanasi dengan Menggunakan Model Pembelajaran CIRC di Kelas XI SMAN 1 Parongpong Tahun Pembelajaran 2017/2018. Skripsi. Bandung: Universitas Pasundan.

Khasanah. 2017. Pengaruh Media Pembelajaran Visual Berbasis Lectora Terhadap Hasil Belajar Kompetensi Perbaikan Kerusakan Mesin Jahit Siswa Kelas X SMK Negeri Klaten. Skripsi. Yogyakarta: Universitas Negeri Yogyakarta.

Kosasih, E. 2014.Jenis-jenis Teks. Bandung: Yrama Widya.

Noviani, Siska Ulfa. 2015. Peningkatan Keterampilan Menyusun Teks Eksplanasi Secara Tertulis Menggunakan Model Pembelajaran Berbasis Masalah Pada Peserta Didik VII A SMP Negeri 19 Tegal Tahun Pelajaran 2015/2015.Skripsi.Semarang: Universitas Negeri Semarang.

Raharjo, Miftahudin. 2011. Penerapan Multimedia Berbasis Ulead Video Studio dalam Pembelajaran Model Discovery Learning sebagai Upaya Meningkatkan Kualitas Pembelajaran Sistem Pengapian Konvensional. Skripsi.Semarang: Universitas Negeri Semarang.

Shofiah, dkk. 2016. Penentuan Tingkat Kesulitan Teks Berdasarkan Pengetahuan Dunia Siswa.Jurnal Pendidikan. Vol.(1): 3.

Taradipta, Reda. 2013. Pengaruh Kombinasi Media Pembelajaran Terhadap Minat Belajar Mahasiswa Pada Mata Kuliah Teknologi Pembelajaran Akuntansi.Jurnal Pendidikan. Volume (2):1. 